\title{
REFLEXOS DA LIBERAÇÃO DA MACONHA SOBRE O MEIO AMBIENTE
}

\author{
EFFECTS OF THE MARIJUANA LIBERATION ON THE ENVIRONMENT
}

\author{
REFLEJOS DE LA LIBERACIÓN DEL CANNABIS EN EL MEDIO AMBIENTE
}

\author{
VLADIMIR PASSOS DE FREITAS \\ https://orcid.org/0000-0001-7693-6858 / http://lattes.cnpq.br/0726419865023009 / vladimir.freitas@terra.com.br \\ Pontifícia Universidade Católica do Paraná, PUCPR. \\ Curitiba, PR, Brasil.
}

\begin{abstract}
RESUMO
O objetivo deste artigo é a análise dos efeitos do plantio da maconha sobre o meio ambiente. A investigação científica utilizou os métodos comparativo e dedutivo. 0 primeiro, através da legislação de outros países. 0 segundo, valendose de pesquisa bibliográfica e documental, aquela com a utilização de fontes doutrinárias, legislativas e jurisprudenciais, esta valendo-se de dados de órgãos oficiais e notícias dos meios de comunicação. A pesquisa, em um primeiro momento, promove o levantamento da legislação sobre o uso da maconha no Brasil e em outros países, em especial nos Estados Unidos da América, onde o federalismo adotado dá poderes aos estados membros para legislar sobre Direito Penal. Em seguida, países em que é permitido o cultivo da maconha para fins medicinais e os efeitos econômicos de tal atividade. Finalmente, os reflexos sobre o meio ambiente. Neste tópico é avaliada a situação do plantio em larga escala, caso venha a ser permitido no Brasil, tendo em vista nossas condições climáticas. Ao final, é apresentada uma conclusão sobre a solução mais razoável para eventual liberação e uso medicinal, bem como sobre os impactos que isto traria para o meio ambiente.
\end{abstract}

Palavras-chave: Crime de uso da maconha; maconha e meio ambiente; plantio da maconha; reflexos econômicos; uso medicinal da maconha.

\section{ABSTRACT}

The aim of this article is to analyze the effects of marijuana on the environment. The scientific research used the comparative and deductive methodology. The former through the legislation of other countries. The latter through bibliographic and documentary research, the first one with the use of doctrinal, legislative and jurisprudential sources, making use of data from official bodies and news from the media. The article, first of all, promotes the research of the legislation on the use of marijuana in Brazil and other countries, especially in the United States of America, where the federalism empowers the member states to legislate on criminal law. Then, the countries where marijuana plantation is allowed for medicinal purposes and the economic effects of such activity. After that, the effects on the environment. In this item, an evaluation is made about the situation of large-scale planting, in case it will be allowed in Brazil, in view of our climatic conditions. At the end, a conclusion is presented on the most reasonable solution for the eventual liberation and medicinal use, as well as the impacts that this would bring to the environment.

Keywords: Crime of marijuana use; marijuana and the environment; marijuana plantation; economic reflections; medicinal use of marijuana.

\section{RESUMEN}

El objetivo de este artículo es el análisis de los efectos de la plantación de marihuana en el medio ambiente. La investigación científica utilizó los métodos comparativo y deductivo. El primero, a través de la legislación de otros países. El segundo, a través de investigación bibliográfica y documental, utilizando fuentes doctrinales, legislativas y jurisprudenciales, datos de organismos oficiales y noticias de los medios de comunicación. La investigación, al principio, promueve el levantamiento de la legislación sobre el uso de marihuana en Brasil y otros países, especialmente en los Estados Unidos de América, donde el federalismo adoptado faculta a los estados miembros 
legislar sobre el derecho penal. Luego, países en los que se permite el cultivo de marihuana con fines medicinales y los efectos económicos de dicha actividad. Finalmente, los efectos sobre el medio ambiente. Este ítem evalúa la situación de la plantación a gran escala, si se permite en Brasil, dadas nuestras condiciones climáticas. Al final, se presenta una conclusión sobre la solución más razonable para una eventual liberación y uso médico, así como sobre los impactos que esto tendría en el medio ambiente.

Palabras clave: Crimen de uso de la marihuana; marihuana y medio ambiente; plantación de la marihuana; reflejos económicos; uso medicinal de marihuana.

\section{SUMÁRIO}

INTRODUÇAO; 1 A CRIMINALIZAÇÃO DO USO DA MACONHA NO BRASIL; 2 A CRIMINALIZAÇÃO DO USO DA MACONHA EM OUTROS PAÍSES; 3 O USO TERAPÊUTICO DA MACONHA; 4 EXPLORAÇAÕ ECONÔMICA DA MACONHA; 5 REFLEXOS SOBRE O MEIO AMBIENTE; CONCLUSÃO; REFERÊNCIAS.

\section{INTRODUÇÃO}

A maconha, como é conhecida no Brasil, tem vários sinônimos: marijuana, daga, diamba, skank, erva maldita e outros tantos. Contudo, seu nome científico é Cannabis sativa, nome este que the foi atribuído pelo sueco Carolos Linnaeus, em 1753.

O uso da Cannabis sempre foi comum nas civilizações antigas da Ásia e, posteriormente, na Europa e na África. Ivan Mario Braun observa que "por volta do século XI a.C., o cânhamo (planta de origem da maconha, haxixe etc.) já era conhecido dos assírios, que o denominavam cunubu ou cunabu - de onde proveio o termo grego e latino Cannabis e a palavra cânhamo".

Ela sempre foi fonte de fibras e se prestou para elaboração de tecidos, cordas e velas de navios. Os indianos, segundo Jean Marcel Carvalho França, ${ }^{2}$ utilizaram-na também como fonte de prazer, tendo colaborado para a "disseminação da planta e dos seus usos no Oriente Médio, na África e Europa”. Porém, relata o referido autor:

Foi, no entanto, na Península Ibérica e por meio dos árabes que teve início na Europa, por volta do século XII, na região de Alicante, na Espanha mourisca, um dos usos mais importantes da fibra do cânhamo no continente: a produção de papel. $^{3}$

Segundo Laura Bonfá e outros, ${ }^{4}$ na Europa, em 1799, Napoleão Bonaparte, ao retornar do Egito, apresentou amostras de Cannabis que despertaram "o interesse da comunidade

\footnotetext{
1 BRAUN, Ivan Mario. Drogas: perguntas e respostas. São Paulo: MG, 2007, p. 120.

2 FRANÇA, Jean Marcel Carvalho. História da maconha no Brasil. São Paulo: Três Estrelas, 2015, p. 8.

${ }^{3}$ FRANCA, Jean Marcel Carvalho. História da maconha no Brasil. São Paulo: Três Estrelas, 2015, p. 8.

${ }^{4}$ BONFÁ, Laura; VINAGRE, Ronaldo C. O.; FIGUEIREDO, Núbia V. Uso de canabinóides na dor crônica e em cuidados paliativos. Revista Brasileira de Anestesiologia, vol. 58, n. 3, maio/jun. 2008, p. 268.
} 
científica pelos seus efeitos sedativos e de alívio da dor”. Registram referidos autores ${ }^{5}$ (2008, p. 268), contudo, que a Cannabis sativa só passou a ser reconhecida no século XIX, por meio do médico irlandês William Brooke O'Shaughnessy, que publicou, em 1839, o artigo On the preparation of the Indian Hemp, or Gunjah na revista Journal of the Asiatic Society of Bengal, no qual relatou "o uso de altas doses de Cs [Cannabis sativa] no tratamento de desordens espásticas e convulsivas, como tétano, hidrofobia, cólera e delirium tremens".

No Brasil, a fibra do cânhamo foi introduzida pelos portugueses para o uso de velas nas embarcações de Portugal. Segundo Jean Marcel Carvalho França, ${ }^{6}$ "em 1772, o vice-rei, marquês de Lavradio, tentou incentivar a sua cultural no Sul do Brasil, mandando para lá um entendido em seu cultivo e umas tantas sacas de sementes”. Sua utilização, no entanto, nunca chegou a ter expressão comercial. Do ponto de vista de recreação, sempre foi vista como algo de pessoas de baixo estrato social. Afirma Jean Marcel Carvalho França:

[...] foram os africanos e seus descendentes que consolidaram o hábito do canibismo na sociedade local. Foram a eles que os brasileiros associaram o gosto 'pela "diamba" (bangue, maconha, fumo de Angola, pito de panga, riamba, liamba, etc.) e seu consumo regular, recreativo e relaxante: e foram eles que os "doutores" (psiquiatras e juristas) de início do século XX, ao promoverem um combate feroz ao canibismo, resolveram culpar por propagar o "nefando vício" pela sociedade brasileira. ${ }^{7}$

Neste artigo, após o levantamento da legislação sobre o uso da maconha no Brasil e no exterior, a análise do seu cultivo para fins medicinais, as relações entre tal atividade e a economia, pretende-se chegar a uma conclusão sobre os reflexos de tal prática sobre o meio ambiente, sendo este o principal foco da investigação científica.

\section{A CRIMINALIZAÇÃO DO USO DA MACONHA NO BRASIL}

Os efeitos da maconha sobre o meio ambiente estão diretamente ligados à sua liberação pelo Estado. Evidentemente, se o plantio for reprimido e, consequentemente, menor, os reflexos ambientais serão de menor monta. No âmbito da repressão o papel mais importante cabe ao Direito Penal, razão pela qual impõe-se uma análise de como se dá, neste aspecto, a tutela estatal.

\footnotetext{
${ }^{5}$ BONFÁ, Laura; VINAGRE, Ronaldo C. O.; FIGUEIREDO, Núbia V. Uso de canabinóides na dor crônica e em cuidados paliativos. Revista Brasileira de Anestesiologia, vol. 58, n. 3, maio/jun. 2008, p. 268.

${ }^{6}$ FRANÇA, Jean Marcel Carvalho. História da maconha no Brasil. São Paulo: Três Estrelas, 2015, p. 10.

${ }^{7}$ FRANÇA, Jean Marcel Carvalho. História da maconha no Brasil. São Paulo: Três Estrelas, 2015, p. 28.
} 
REFLEXOS DA LIBERAÇÃO DA MACONHA SOBRE O MEIO AMBIENTE

O Brasil, na maior parte do tempo em que foi Colônia de Portugal, regeu-se pelas Ordenações Filipinas. Nelas, os crimes estavam previstos no Capítulo V. ${ }^{8}$ A Proclamação da Independência, em 1822, resultou na revogação das leis do Brasil Colônia. O novo Código Criminal entrou em vigor através de Lei de 16 de dezembro de $1830 .{ }^{9}$ Não havia nenhum capítulo destinado aos delitos contra a saúde e muito menos referente ao uso ou tráfico de drogas.

Proclamada a República, o Decreto $\mathrm{n}^{\circ} 847$, de 11 de outubro de 1890, introduziu em nossa legislação o Código Penal dos Estados Unidos do Brazil. ${ }^{10}$ Os crimes contra a saúde foram tratados no Capítulo III, artigos 156 a 164, mas nada se dispôs sobre o uso ou o comércio de entorpecentes.

O uso da maconha veio a tornar-se crime através do Decreto $n^{\circ} 20.930$, de 11 de janeiro de 1932, que incluiu no artigo $1^{\circ}$, inciso XII, a Cannabis indica como uma das substâncias tóxicas entorpecentes, punindo quem a portasse ou a armazenasse com sanção de 3 (três) a 9 (nove) meses de prisão celular e multa.

Poucos anos depois, mais exatamente em 1940, o Código Penal trouxe previsão de crime pelo uso de entorpecentes, punindo-o da mesma forma que o comércio e o tráfico:

Art. 281. Importar ou exportar, vender ou expor à venda, fornecer, ainda que a título gratuito, transportar, trazer consigo, ter em depósito, guardar, ministrar ou, de qualquer maneira, entregar a consumo substância entorpecente, sem autorização ou em desacordo com determinação legal ou regulamentar:

Pena - reclusão, de um a cinco anos, e multa, de dois a dez contos de réis. ${ }^{11}$

O Decreto-lei $n^{\circ} 385$, de 26 de dezembro de 1968, deu nova redação ao artigo 281 , § $1^{\circ}$ da lei penal, adicionando o inciso III, mais específico sobre o uso, punindo sua infração com prisão de um a cinco anos de reclusão e multa de 10 a 50 vezes o maior salário-mínimo vigente no país. Eis a redação:

$\S 1^{\circ}$ Nas mesmas penas incorre quem ilegalmente:

III - traz consigo, para uso próprio, substância entorpecente ou que determine dependência física ou psíquica. (Matérias-primas ou plantas destinadas à

8 PORTUGAL. Ordenações Filipinas: Livro V. Disponível em: http://www1.ci.uc.pt/ihti/proj/filipinas/l5ind.htm. Acesso em: 25 jul. 2018.

${ }_{9}$ BRASIL. Lei de 16 de dezembro de 1830. Manda executar o Codigo Criminal. In: Coleção de Leis do Brasil, Brasília, DF, 1830. Disponível em: http://www.planalto.gov.br/ccivil_03/leis/LIM/LIM-16-121830.htm. Acesso em: 18 jul. 2018.

${ }^{10}$ BRASIL. Decreto $n^{\circ} 847$, de 11 de outubro de 1890. Promulga o Código Penal. In: Coleção de Leis do Brasil, Brasília, DF, 1890. Disponível em: http://www2.camara.leg.br/legin/fed/decret/18241899/decreto-847-11-outubro-1890-503086-publicacaooriginal-1-pe.html. Acesso em: 18 jul. 2018.

11 BRASIL. Decreto-lei $\mathrm{n}^{\circ} 2.848$, de 7 de dezembro de 1940. Código Penal. In: Diário Oficial da União, Brasília, DF, 31 dez. 1940. Disponível em: http://www2.camara.leg.br/legin/fed/declei/19401949/decreto-lei-2848-7-dezembro-1940-412868-publicacaooriginal-1-pe.html. Acesso em; 18 jul. 2018. 
preparação de entorpecentes ou de substâncias que determine dependência física ou psíquica. ${ }^{12}$

Aquele dispositivo legal foi revogado pela Lei $n^{\circ} 6.368,,^{13}$ que separou em artigos distintos o tráfico e o uso, colocando o primeiro no artigo 12 e o segundo no 16. Ao uso, cominou-se a pena de 6 meses a 2 anos de detenção e multa. Portanto, foi abrandada a sanção, evitando o encarceramento do condenado, uma vez que a ele seria concedida, em condições normais, a suspensão condicional da pena.

Quase trinta anos depois, a Lei $n^{\circ} 11.343$, de 23 de agosto de 2006, entre outras coisas, disciplinou o uso de drogas de forma inovadora. Não chegou a liberar o uso, porém suavizou-o, ao estabelecer que:

Art. 28. Quem adquirir, guardar, tiver em depósito, transportar ou trouxer consigo, para consumo pessoal, drogas sem autorização ou em desacordo com determinação legal ou regulamentar será submetido às seguintes penas:

I - advertência sobre os efeitos das drogas;

II - prestação de serviços à comunidade;

III - medida educativa de comparecimento a programa ou curso educativo. ${ }^{14}$

Registre-se que no Supremo Tribunal Federal tramita ação de declaração de inconstitucionalidade dos artigos da referida Lei $n^{\circ} 11.343$, no que toca ao uso e às formas que estão, com ele, relacionadas. ${ }^{15}$ Referida ação originária teve três votos favoráveis, porém seu andamento foi interrompido pelo falecimento do ministro Teori Zavascki, que havia pedido vista dos autos.

12 BRASIL. Decreto-Lei n 385, de 26 de dezembro de 1968. Dá nova redação ao artigo 281 do Código Penal. In: Diário Oficial da União, Brasília, DF, 27 dez. 1968. Disponível em: http://www.planalto.gov.br/ccivil_03/decreto-lei/1965-1988/Del0385.htm\#art281. Acesso em: 18 jul. 2018.

13 BRASIL. Lei $n^{\circ}$ 6.368, de 21 de outubro de 1976. Dispõe sobre medidas de prevenção e repressão ao tráfico ilícito e uso indevido de substâncias entorpecentes ou que determinem dependência física ou psíquica, e dá outras providências. In: Diário Oficial da República Federativa do Brasil, Brasília, DF, 22 out. 1976. Disponível em: http://www.planalto.gov.br/ccivil_03/LEIS/L6368.htm\#art46. Acesso em: 18 jul. 2018.

14 BRASIL. Lei $n^{\circ} 11.343$, de 23 de agosto de 2006. Institui o Sistema Nacional de Políticas Públicas sobre Drogas - Sisnad; prescreve medidas para prevenção do uso indevido, atenção e reinserção social de usuários e dependentes de drogas; estabelece normas para repressão à produção não autorizada e ao tráfico ilícito de drogas; define crimes e dá outras providências. In: Diário Oficial da República Federativa do Brasil, Brasília, DF, 24 ago. 2006. Disponível em: http://www.planalto.gov.br/ccivil_03/_Ato2004-2006/2006/Lei/L11343.htm\#art75. Acesso em: 18 jul. 2018.

${ }^{15}$ BRASIL. Supremo Tribunal Federal. Ação Direta de Inconstitucionalidade $n^{\circ}$ 635.659. Relator: Ministro Gilmar Mendes, distribuída em 1 de março de 2011. Disponível em: http://www.stf.jus.br/portal/processo/verProcessoAndamento.asp?incidente=4034145. Acesso em: 16 ago. 2018. 
No entanto, no estágio atual, ainda que sem declaração de inconstitucionalidade, a punição pelo uso tornou-se mais do que tudo simbólica, porque todas as suas formas são de natureza mais preventiva que sancionadora.

\section{A CRIMINALIZAÇÃO DO USO DA MACONHA EM OUTROS PAÍSES}

A Convenção das Nações Unidas contra o Tráfico Ilícito de Estupefacientes e de Substâncias Psicotrópicas, de 1988, da qual o Brasil é signatário, direcionou o foco do combate aos traficantes e suas organizações criminosas, reconhecendo nas suas considerações o fato de que eles "minam as economias lícitas que ameaçam a estabilidade, a segurança e a soberania dos Estados". ${ }^{16} \mathrm{Na}$ busca de solução ao grave problema, convencionou-se que se daria especial combate à economia dos transgressores, para tanto, prevendo-se o confisco de seus bens (artigo 5, itens 1 a 9).

Por outro lado, o uso de entorpecentes, entre eles a maconha, foi excluído da Convenção Internacional, ficando cada país livre para dar ao assunto o tratamento que melhor se adequasse à sua realidade. Os Países Baixos, outrora conhecidos como Holanda, regulam o uso do ópio e outras substâncias entorpecentes, através da Lei de 12 de maio de 1928, conhecida como Opium Act. ${ }^{17}$ Desde 1976, com a revisão do Opium Act pelo parlamento, criou-se uma distinção formal entre a Cannabis, que é considerada de menor risco, e outras drogas consideradas nocivas, como a cocaína, a heroína e o LSD. (arts. 8h, 8i, 11 §§ 5 e 6).

Em 13 de julho de 2002 foi promulgada lei que alterou parcialmente a Opium Act e, na mesma data, o Decreto 520, que atualizou as listas I e II a ele anexas. Pela legislação neerlandesa, a Cannabis é formalmente ilegal (arts. 1 e 2). No entanto, as decisões do Poder Judiciário definiram a existência de tolerância quanto à posse de uma pequena quantidade e a venda em determinadas condições estritas.

Apesar de a venda de drogas leves ser considerada crime, é acordado socialmente que os coffeeshops que venderem pequenas quantidades não serão processados. Todavia, devem estar de acordo com uma série de condições impostas pelo governo que, sintetizando, consistem em: não causar incômodo; não vender drogas pesadas; não vender para menores; não fazer

16 BRASIL. Decreto $n^{\circ} 154$, de 26 de junho de 1991. Promulga a Convenção Contra o Tráfico llícito de Entorpecentes e Substâncias Psicotrópicas. In: Diário Oficial da União, Brasília, DF, 27 dez. 1968. Disponível em: http://www.planalto.gov.br/ccivil_03/decreto/1990-1994/D0154.htm. Acesso em: 3 ago. 2018.

17 HOLANDA. Opiumwet (Opium Act). WHO MiNDbank Collection: 12 de maio de 1928. Disponível em: https://www.mindbank.info/item/2026. Acesso em: 06 ago. 2018. 
propaganda de drogas; não vender grandes quantidades (mais de 5 gramas de Cannabis) em uma única transação. ${ }^{18}$

Em Amsterdã os turistas maiores de 18 anos podem comprar, mas, nas outras cidades, apenas os nacionais ou residentes. 0 consumo, todavia, deve ser feito dentro dos cafés e não nas ruas. Também não serão processados, mas poderão sofrer punição, os maiores de 18 anos que forem flagrados com até 5 gramas de Cannabis ou outra droga considerada leve. ${ }^{19}$ Registre-se que as drogas consideradas leves são as que se encontram na lista 2, anexa ao Opium Act, e pesadas são aquelas indicadas na lista 1 da mesma lei.

Registre-se, contudo, que, segundo análise da The Economist, "o número de coffeeshops já vem diminuindo há muitos anos”. Em 1995, eram 350. Atualmente, são $167 .{ }^{20} \mathrm{Na}$ verdade, nos Países Baixos há um movimento de resistência à venda da maconha em Amsterdã, principalmente a turistas, sob a alegação de que isto depõe contra o conceito do país e atrai pessoas de má índole.

Em Portugal, a fim de adequar o ordenamento interno à Convenção das Nações Unidas contra o Tráfico llícito de Estupefacientes de 1988, foi aprovado e promulgado o Decreto-Lei $n^{\circ}$ 15/93, denominado Legislação de Combate à Droga. Contudo, foi através da Lei $n^{\circ} 30 / 2000$, aprovada em 2001, que o país, entendendo o problema das drogas como questão de saúde pública, descriminalizou a aquisição e detenção para consumo próprio e desde que não exceda a quantidade necessária para o consumo médio individual durante 10 dias (art. $2^{\circ}$ ). No entanto, manteve-se proibido o cultivo da Cannabis.

Assim, o consumidor que for flagrado portando drogas não poderá ser preso, mas poderá ser identificado pelas autoridades e ter as substâncias encontradas em sua posse apreendidas $\left(\right.$ art. $\left.4^{\circ}\right)$. As autoridades também poderão encaminhar o auto da ocorrência para a Comissão de Dissuasão da Toxicodependência, formada por um jurista e dois outros profissionais com

18 HOLANDA. Toleration policy regarding soft drugs and coffee shops. Disponível em: https://www.government.nl/topics/drugs/toleration-policy-regarding-soft-drugs-and-coffee-shops. Acesso em: 06 ago. 2018.

${ }^{19}$ HOLANDA. Am I committing a criminal offence if I possess, produce or deal in drugs? Disponível em: https://www.government.nl/topics/drugs/am-i-committing-a-criminal-offence-if-i-possess-produce-ordeal-in-drugs. Acesso em: 06 ago. 2018.

20 ÉPOCA NEGÓCIOS. Por que os coffeeshops de Amsterdã estão fechando? Época Negócios Online, 03 fev. 2017. Disponível em: https://epocanegocios.globo.com/colunas/Coffee-Break/noticia/2017/02/por-queos-coffeeshops-de-amsterda-estao-fechando.html. Acesso em: 06 ago. 2018. 
REFLEXOS DA LIBERAÇÃO DA MACONHA SOBRE O MEIO AMBIENTE

currículo adequado na área de toxicodependência - médicos, psicólogos, sociólogos, etc. (art. $\left.7^{\circ}\right) .{ }^{21} \mathrm{~A}$ iniciativa revelou-se exitosa, graças à excelência do sistema de saúde daquele país.

No Uruguai surgiu a primeira abertura da América Latina. A Lei $n^{\circ} 19.172$, de 7 de janeiro de $2014,{ }^{22}$ declarou ser atribuição do Estado todas as atividades relacionadas com a importação, exportação, plantação, cultivo, colheita, produção, aquisição a qualquer título, armazenamento, comercialização e distribuição da Cannabis e seus derivados.

A lei referida visou proteger os uruguaios do risco do relacionamento com os traficantes de drogas. 0 uso da droga para fins medicinais tornou-se permitido na quantidade de até 40 gramas por mês. A mesma quantidade é considerada como de consumo pessoal, sendo possível cultivar até seis pés de maconha com tal finalidade. Podem ser criados clubes de cultivo e consumo, que devem ter de 15 a 45 membros.

Os usuários devem ser registrados junto ao poder público, ter 18 anos e as vendas são feitas em farmácias. 0 tráfico de drogas continua sendo punido pelo Decreto-Lei 14.294, de 31 de outubro de 1974, artigo 30, com pena de 3 (três) a 10 (dez) anos de prisão, havendo formas qualificadas. $^{23}$

Passados cinco anos da nova legislação, os resultados não têm sido muito animadores. 0 mercado de consumidores cresceu e o Estado não consegue fornecer a droga a todos os interessados, disto resultando a formação de quadrilhas nacionais e internacionais que fornecem a substância ilegalmente, gerando violência e insegurança. 0 número de homicídios, no ano de 2018, superou em 35\% a mesma ocorrência em 2017. ${ }^{24}$

No Canadá o Senado aprovou, em 19 de junho de 2018, uma lei que libera o uso recreativo da maconha, através da qual "será possível comprar maconha de produtores licenciados na internet e também em lojas especializadas na venda no varejo. Adultos poderão portar até 30 gramas em público". ${ }^{25}$ Porém, é nos Estados Unidos que o assunto desperta maior

21 MENDES, Oro. 14 anos após descriminalizar todas as drogas, é assim que Portugal está no momento. Awebic, 07 fev. 2018. Disponível em: https://awebic.com/democracia/como-portugal-descriminalizou-asdrogas-e-e-um-exemplo-para-o-mundo/. Acesso em: 06 ago. 2018.

22 URUGUAI. Lei $\mathrm{n}^{\circ}$ 19.172, de 7 de janeiro de 2014. Disponível em: https: / /legislativo.parlamento.gub.uy/temporales/leytemp6844441.htm. Acesso em: 3 ago. 2018.

23 URUGUAI. Decreto-Lei 14.294, de 31 de outubro de 1974. Disponível em: https: / /legislativo.parlamento.gub.uy/temporales/leytemp7057670.htm. Acesso em: 3 ago. 2018.

24 GAÚCHAZH. Disputa por mercado de maconha provoca aumento no índice de homicídios no Uruguai. Disponível em: https://gauchazh.clicrbs.com.br/grupo-de-investigacao/noticia/2019/01/disputa-pormercado-de-maconha-provoca-aumento-no-indice-de-homicidios-no-uruguai-

cjr2blcwd01pl01pkcb2wmgry.html. Acesso em: 25 jul. 2019.

${ }^{25}$ BBC. Canadá legaliza uso recreativo da maconha: saiba em que lugares o uso da droga é permitido. BBC News Brasil, 20 jun. 2018. Disponível em: https://www.bbc.com/portuguese/internacional-44545870. Acesso em: 19 ago. 2018. 
atenção, não só pela posição econômica daquele país na esfera internacional, como pelo fato de tratar-se de uma federação, com nada menos do que 50 (cinquenta) leis estaduais. Portanto, uma fonte de pesquisa muito rica.

Vários sítios na internet fornecem dados a respeito da legislação estadual norteamericana sobre o assunto. Cita-se, todavia, um que é explícito sobre a situação atual em cada estado membro. Trata-se do "NORML Blog - Working to reform marijuana laws". ${ }^{26}$ Nele, o pesquisador tem o mapa do país e a possibilidade de saber qual é o tratamento legal dispensado por cada estado. Vejamos alguns exemplos.

No Estado do Colorado, a sanção ao usuário da maconha depende da quantidade encontrada. ${ }^{27}$ Até uma onça, medida que equivale a 28,34 gramas, não há penalidade. Fornecer a terceiro, na mesma quantidade, idem. Mais de uma onça até duas, pena de multa de U\$ 100 . De duas a seis onças, a sanção será de prisão até 12 meses e multa de U\$ 700. De seis a doze onças, prisão de 6 a 18 meses e multa de U\$ 5,000. Mais de 12 onças, ou seja, 340,08 gramas, considera-se crime sancionado com 1 a 2 anos de prisão e U\$ 100,000 de multa. 0 cultivo até 6 pés da erva é permitido e o tráfico é punido severamente, podendo, em casos extremos, chegar a 32 anos de prisão.

Mas no Estado de Kansas, vizinho ao lado direito do Colorado, a simples posse é reprimida com 6 meses de prisão e U\$ 1,000 de multa, o tráfico, na proximidade até 1.000 pés de uma escola, pode ser sancionado com até 7 anos de prisão e o cultivo é permitido até 4 plantas. ${ }^{28}$ No Wyoming, ao norte, a posse, o cultivo e o tráfico são punidos, o que demonstra maior rigor na forma de tratar a matéria. ${ }^{29}$ Do outro lado do país, no extremo norte da costa leste, o Maine não pune a posse até duas onças e meia, porém reprime com 10 anos de prisão possuir mais de 20 libras, o que equivale a 9.060 gramas ou pouco mais de 9 quilos. 0 uso em locais públicos é punido com multa de U\$ 100 (cem dólares) e permite-se o plantio de até três pés por pessoa. ${ }^{30}$

Como se vê, há uma tendência no mundo ocidental no sentido de abrandar as sanções para o uso da maconha. No entanto, isto depende da legislação interna de cada país e a

\footnotetext{
${ }^{26}$ NORML. State Laws. Disponível em: http://norml.org/laws. Acesso em: 19 ago. 2018.

27 NORML. Colorado laws and penalties. Disponível em: http://norml.org/laws/item/colorado-penalties. Acesso em: 19 ago. 2018.

28 NORML. Kansas laws and penalties. 2018b. Disponível em: http://norml.org/laws/item/kansaspenalties-2. Acesso em: 19 ago. 2018.

${ }^{29}$ NORML. Wyoming laws and penalties. Disponível em: http://norml.org/laws/item/wyoming-penalties2. Acesso em: 19 ago. 2018.

${ }_{30}$ NORML. Maine laws and penalties. Disponível em: http://norml.org/laws/item/maine-penalties-2. Acesso em: 19 ago. 2018.
} 
diferença de tratamento perdurará por muitos anos, estando sempre relacionada com as peculiaridades locais, inclusive sociais e econômicas. Por outro lado, cumpre registrar que em outras regiões do planeta a abordagem tem sido diferente. Tomando a Ásia como exemplo, vejamos qual é o tratamento dado pela legislação em três países daquela região.

Em Singapura, a Lei de 1973, conhecida como Misuse of drugs act (Lei de uso indevido de drogas), ${ }^{31}$ dispõe no art. 5, combinado com o que consta no Segundo Anexo, sobre diversas possibilidades de imposição de pena de morte por tráfico de drogas. Contudo, ao contrário do Brasil, a sanção varia conforme o tipo de droga ilícita. Por exemplo, em se tratando de maconha, se a quantidade for de 330 a 499 gramas a pena será de, no máximo, 30 anos ou prisão perpétua, mais 14 chibatadas. Contudo, se a quantia for de 500 ou mais gramas, a pena será de morte.

$\mathrm{Na}$ Indonésia, existem duas leis tratando do tema. A primeira, Lei $\mathrm{n}^{\circ} 5$, de 1997, que trata de Drogas Psicotrópicas, ${ }^{32}$ dispõe no art. 59 que aqueles que praticam o tráfico com características de crime organizado podem ser punidos com pena de morte, prisão perpétua ou prisão por 20 anos, além da multa no valor de 750,000,000 (setecentos e cinquenta milhões de rúpias), ou seja, $\mathrm{R} \$ 199.000,43$ (cento e noventa e nove mil reais com quarenta e três centavos). A segunda é a Lei $n^{\circ} 35,{ }^{33}$ sobre narcóticos. Esta, no art. 118, dispõe que aquele que pratica tráfico de narcóticos em quantidade acima de 5 gramas será punido com pena de morte, prisão perpétua ou prisão por 5 a 20 anos, além de multa, que poderá ser de 800.000.000,00 (oitocentos milhões) a 8.000.000.000.00 (oito bilhões de rúpias), equivalendo a importância máxima a R\$2.162.494,00 (dois milhões, cento e sessenta e dois mil, quatrocentos e noventa e quatro reais).

Nas Filipinas, a matéria é regulada pelo Ato da República $n^{\circ} 9.165$, de 2002, conhecido como Lei de Drogas Perigosas Abrangentes. Nele, a pena de morte não é permitida, porém há previsão, na seção 27 , de imposição de prisão perpétua, além da multa. ${ }^{34}$ Todavia, a Câmara dos

31 SINGAPURA. Misuse of drugs act (Chapter 185). Revised edition 2008 (Original enactment: act 5 of 1973). Singapore statutes online. Disponível em: https://sso.agc.gov.sg/Act/MDA1973. Acesso em: 27 nov. 2018.

32 INDONÉSIA. Lei $\mathrm{n}^{\circ} 5$, de 1997. On psychotropic substances. Disponível em: https://www.unodc.org/res/cld/document/idn/law-no-5_html/indonesia-law_5_of_97.pdf. Acesso em: 27 nov. 2018.

33 INDONÉSIA, Lei $\mathrm{n}^{\circ}$ 35, de 2009. Disponível em: < http://www.flevin.com/id/lgso/translations/JICA\%20Mirror/english/4868_UU_35_2009_e.html>. Acesso em: 27 nov, 2018.

34 FILIPINAS. Comprehensive dangerous drugs act of 2002. Disponível em: https://www.wipo.int/wipolex/en/text.jsp?file_id=480318,\%20filipinas. Acesso em 27 nov. 2018. 
REFLEXOS DA LIBERAÇÃO DA MACONHA SOBRE O MEIO AMBIENTE

Representantes votou para restabelecer a pena de morte por crimes de drogas em março de 2017, mas a lei ainda está pendente de aprovação do Senado e de sanção presidencial. ${ }^{35}$

\section{O USO TERAPÊUTICO DA MACONHA}

O reconhecimento do potencial terapêutico da Cannabis sativa acompanha a história da humanidade há milhares de anos. De acordo com Harold Kalant, ${ }^{36}$ "fatores geográficos e climáticos modificam o conteúdo de material farmacologicamente ativo na planta, e somente em algumas regiões esse teor é alto o suficiente para levar à descoberta de que a planta e, especialmente, sua resina, possui ações medicamentosas”. Em razão desses aspectos, a inserção da Cannabis na medicina popular teve seu começo no Himalaia, na Ásia Central, espalhando-se gradativamente pela Índia, Ásia Menor e África.

0 primeiro relato sobre as propriedades medicinais da Cannabis sativa está incorporado na Pen-Ts'ao Ching, escrita há cerca de 2.737 anos A.E.C, e considerada a primeira farmacopeia do mundo. Laura Bonfá et al. ${ }^{37}$ e Káthia M. Honório et al. ${ }^{38}$ relatam que o imperador Shen-Nung, considerado o pai da medicina oriental, prescrevia a chu-ma (cânhamo fêmea) para o tratamento de beribéri, malária, gota, reumatismo, constipação, fadiga e problemas menstruais. De acordo com Robinson Rowan, ${ }^{39}$ o imperador a classificava como "um dos Supremos Elixires da Imortalidade".

O psiquiatra francês Moreau de Tours, durante uma viagem no norte da África em 1830, identificou os efeitos do uso do haxixe na alteração do sistema nervoso central e os tratou em sua obra "O Haxixe e a Alienação Mental". ${ }^{40}$ Em tempos mais recentes, a legislação de vários países vem se amoldando a um perfil mais concessivo em termos de tratamento médico.

\footnotetext{
35 FILIPINAS. Câmara das Filipinas aprova pena de morte para crime relacionado a droga. Folha de São Paulo (digital), caderno Mundo, 7/3/2017. Disponível em: https: / / www1.folha.uol.com.br/mundo/2017/03/1864279-camara-das-filipinas-aprova-pena-de-mortepara-crime-relacionado-a-droga.shtml. Acesso em 27 nov. 2018.

36 KALANT, Harold. Medicinal use of Cannabis: history and current status. Pain Research and Management, vol. 6, n. 2, summer 2001, p. 81.

37 BONFÁ, Laura; VINAGRE, Ronaldo C. O.; FIGUEIREDO, Núbia V. Uso de canabinóides na dor crônica e em cuidados paliativos. Revista Brasileira de Anestesiologia, v. 58, n. 3, mai/jun. 2008, p. 268.

38 HONÓRIO, Káthia Maria; ARROIO, Agnaldo; SILVA, Albérico B. F. Aspectos terapêuticos de compostos da planta Cannabis sativa. Química Nova, vol. 23, n. 2, pp. 318-325, 2006, p. 318.

39 ROWAN, Robinson. 0 grande livro da Cannabis: guia completo de seu uso industrial, medicinal e ambiental. Rio de Janeiro: Jorge Zahar, 1999, p. 31.

40 KALANT, Harold. Medicinal use of cannabis: history and current status. Pain Research and Management, vol. 6, n. 2, summer 2001, p. 81.
} 
REFLEXOS DA LIBERAÇÃO DA MACONHA SOBRE O MEIO AMBIENTE

Em Israel o uso para fins de recreação é proibido, mas, para tratamento de determinadas doenças, é permitido desde $1992 .{ }^{41}$ No Canadá é possível o consumo da maconha, se 0 interessado tiver receita médica e uma autorização emitida pelo governo. ${ }^{42} \mathrm{Em}$ Portugal o uso da Cannabis para fim medicinal foi permitido através da Lei 33, de 18 de julho de $2018 .{ }^{43}$ Chile, México, Argentina e Colômbia procedem da mesma forma. ${ }^{44}$

Nos Estados Unidos da América é permitido o plantio terapêutico em 29 estados e em Washington D.C. ${ }^{45}$ Por exemplo, no conservador Estado de Kentucky não há possibilidade de plantio para uso medicinal. ${ }^{46}$ Já no Estado de Virgínia, é permitida a pesquisa e o tratamento com espécie rica em canabinoides (CBD), que podem ser utilizados em medicamentos, e que seja pobre em Tetrahidrocanabinol (THC), que gera efeitos psicoativos. ${ }^{47}$ Todavia, é necessário que um médico tenha recomendado tal tratamento, esclarecendo a razão da necessidade.

No Brasil o plantio para fins medicinais está proibido. É certo que a Agência Nacional de Vigilância Sanitária - ANVISA reconheceu a maconha como planta medicinal, incluindo-a na Lista Completa das Denominações Comuns Brasileiras (DCB). ${ }^{48}$ No entanto, isto não autoriza o plantio.

Apontam Zaganelli e Correia as possibilidades de uso terapêutico da maconha, exemplificando:

Nesta senda, pode-se destacar algumas possibilidades de utilização dos canabinoides no tratamento de doenças. Uma das características marcantes da

\footnotetext{
41 JESUS, Antonio Carlos Justo de; FERNANDES, Luis Rodrigues; ELIAS, Paloma Sampaio; SOUZA, André Ricardo Gomes de. Legalização da maconha para fins medicinais. Revista do Curso de Direito da Universidade Braz Cubas, v. 1, n. 1, maio 2017. Disponível em: https://revistas.brazcubas.br/index.php/revdubc/article/view/247/399. Acesso em: 12 ago. 2018.

${ }^{42}$ G1. Veja como é a legislação relativa à maconha em outros países. G1 Mundo, $10 \mathrm{dez}$. 2013. Disponível em: http://g1.globo.com/mundo/noticia/2013/12/veja-como-e-legislacao-relativa-maconha-em-outrospaises.html. Acesso em: 12 ago. 2018.

${ }^{43}$ PORTUGAL. Lei nº 33, de 18 de julho de 2018. In: DRE - Diário da República Eletrônico, n. ${ }^{\circ}$ 137/2018. Disponível em: https://dre.pt/home/-/dre/115712242/details/maximized. Acesso em: 04 ago. 2018.

${ }^{44} \mathrm{BBC}$. Canadá legaliza uso recreativo da maconha: saiba em que lugares o uso da droga é permitido. BBC News Brasil, 20 jun. 2018. Disponível em: https://www.bbc.com/portuguese/internacional-44545870. Acesso em: 19 ago. 2018.

45 TRUMBLE, Sarah; DECKER, James. Map of State Marijuana Legalization Laws. Third Way, 2 fev. 2018. Disponível em: https://www.thirdway.org/infographic/map-of-state-marijuana-legalization-laws. Acesso em: 04 ago. 2018.

${ }^{46}$ NORML. Kentucky laws and penalties. Disponível em: http://norml.org/laws/item/kentucky-penalties2. Acesso em: 19 ago. 2018.

${ }_{47}^{47}$ NORML. Virginia laws and penalties. Disponível em: http://norml.org/laws/item/virginia-penalties-2. Acesso em: 19 ago. 2018.

48 VEJA. Anvisa reconhece 'Cannabis sativa' como planta medicinal. Veja Saúde, 16 maio 2017. Disponível em: https://veja.abril.com.br/saude/anvisa-reconhece-Cannabis-sativa-como-planta-medicinal/. Acesso em: 04 ago. 2018.
} 
Cannabis sob o organismo humano são os efeitos no sistema nervoso. Com isso, o efeito de analgesia é uma das possibilidades para tratamento de dor, principalmente em situações que os remédios convencionais não proporcionam devida qualidade de vida; a utilização da maconha pode reduzir os sintomas e o tratamento quimioterápico em pacientes oncológicos32; uma forma muito conhecida e que mais incita a busca pela legalização é a esclerose múltipla e as síndromes epiléticas. 0 potencial anticonvulsivo e a atuação neurológica auxiliam na diminuição dos sintomas dessas enfermidades. ${ }^{49}$

Atualmente, quem deseja valer-se de tratamento de tal tipo tem duas alternativas. A primeira é importar o insumo. Todavia, para tanto, despenderá quantias mais expressivas, além de enfrentar a burocracia. Consta que:

"O número de importações mostra que já existe um grande mercado para maconha medicinal no Brasil", afirma Gabriel Elias, o coordenador de Relações Institucionais da PBPD.

O preço mínimo de cada um dos produtos é cerca de US\$ 70 (R\$ 250), sem contar as taxas de transporte e importação. Produtos com maior processamento são ainda mais caros - o Mevatyl sai por R\$ 2.896 reais (uma caixa contendo três frascos de $10 \mathrm{ml}) .^{50}$

Visando facilitar a importação e auferir lucros, as empresas Dr. Cannabis e Indeov estabelecem o contato entre médicos que prescrevem tal uso, pacientes interessados e fornecedores do exterior, principalmente Canadá e Estados Unidos da América. ${ }^{51}$

A segunda opção, que é a utilizada por pessoas de baixa renda, é plantar em casa, mediante autorização judicial. Atualmente, há vários precedentes neste sentido. A título de exemplo, um deles é citado. Noticia a mídia que:

O juiz Silvio César Arouck Gemaque, da $9^{\text {a }}$ Vara Criminal da Justiça Federal de São Paulo concedeu salvo-conduto ao designer aposentado, Gilberto Castro (45 anos), para que ele possa plantar até 20 sementes de maconha por mês em sua casa sem sofrer ações de autoridades. Gilberto usa a erva no tratamento de esclerose múltipla. ${ }^{52}$

\footnotetext{
49 ZAGANELLI, Margareth Vetis; CORREIA, João Victor Gomes. A restrição do uso medicinal da cannabis sativa face ao princípio da autonomia da vontade. Revista Eletrônica do Curso de Direito. Universidade Federal de Santa Maria, v. 13, $\mathrm{n}^{\circ}$ 2, 2018, p. 10. Disponível em: https://periodicos.ufsm.br/revistadireito/article/view/29501/pdf. Acesso em 28 jul. 2019.

50 MORI, Letícia. Como o uso de maconha medicinal tem crescido no Brasil. Disponível em: https://www.bbc.com/portuguese/geral-44283537. Acesso em: 27 nov. 2018.

${ }^{51}$ BATISTA, Everton Lopes. Empresas do país ajudam pacientes a achar médicos que prescrevam maconha. Jornal Folha de São Paulo, 30 nov. 2018, p. B5.

52 BRUZA, Rafael. Juiz dá salvo-conduto para paciente plantar maconha com fins medicinais. Independente, 26 maio 2018. Disponível em: http://independente.jor.br/juiz-da-salvo-conduto-parapaciente-plantar-maconha-com-fins-medicinais/. Acesso em: 04 ago. 2018.
} 
No entanto, há que se ter cautela na autorização judicial, uma vez que o plantio poderá tornar-se uma forma de tráfico através do abastecimento de terceiros. É verdade que há situações em que esta é a providência mais adequada diante da situação de fato. Todavia, se pedidos de tal ordem multiplicarem-se, é possível que sejam deferidos indistintamente, seja por não dispor o magistrado de tempo para fazer uma inspeção no local, seja por ter uma visão mais liberal da matéria. Portanto, o ideal é que a lei fixe os limites, reduzindo o subjetivismo.

Registre-se, ainda, que não será fácil, em escala mais ampla, fazer-se o controle das autorizações de uso dadas para fins terapêuticos. Neste particular o papel do médico assume importância ímpar, já que a ele cabe dar a permissão e tal possibilidade não pode transformarse em uma forma de abastecimento de terceiros interessados.

\section{EXPLORAÇÃO ECONÔMICA DA MACONHA}

O tráfico da maconha tem sido uma atividade lucrativa, uma vez que o número de consumidores tem aumentado significativamente, o que é um fato notório. Mas nesta investigação científica o foco é outro, direciona-se para a exploração lícita da referida substância.

A liberação do plantio da maconha nos Estados Unidos, para fins medicinais e, em menor número, para fins recreativos nas sete unidades federativas que admitem tal prática, gerou uma progressista atividade empresarial naquele país. Segundo um relatório da Arcview Market Research, era esperado, com a venda legal de maconha, um investimento de "U\$ 9,7 bilhões na América do Norte em 2017". 53

O mercado econômico é tão promissor que empresas que exploram o plantio de maconha já têm ações na Bolsa de Valores. Consta que "as ações da Tilray produtora canadense de cânabis, estrearam nesta quinta-feira (19) com alta de $32 \%$ na Nasdaq, o mais recente esforço da indústria da maconha para entrar no mercado financeiro convencional". ${ }^{54}$

Diversa é a situação no Uruguai, onde, ao contrário dos demais países:

[...] o Estado controla todo o processo, incluído o design genético da planta, comprado de uma empresa espanhola. Tudo está pensado para tirar do mercado ilegal os 160.000 uruguaios que, em algum momento do ano, fumam maconha, e

\footnotetext{
${ }^{53}$ ROBINSON, Melia. This map shows every state that has legalized marijuana. Business Insider Nordic, 23 jan. 2018. Disponível em: https://nordic.businessinsider.com/legal-marijuana-states-2018-1/. Acesso: 04 ago. 2018.

54 BULLOCK, Nicole. PRIMEIRA produtora de maconha a abrir capital nos EUA estreia com alta de $32 \%$. Folha de São Paulo, São Paulo, A10, 20 jul. 2018.
} 
para acabar com um negócio que rende 30 milhões de dólares $(95,7$ milhões de reais) aos traficantes, além de aumentar a violência e, inclusive, o índice de mortes em um país pouco acostumado à insegurança que assola toda a América Latina. ${ }^{55}$

A inserção da Cannabis no mercado, tanto no que diz respeito ao seu uso recreativo quanto ao medicinal, a priori vem demonstrando resultados positivos na economia dos países que legalizaram o uso. Basta pensar que nos Estados Unidos a maconha medicinal movimentou, em 2017, o equivalente a U\$ 6,7 bilhões, e estima-se que o mercado recreativo esteja atualmente em U\$ 1 bilhão, com expectativas de chegar a US\$ 20 bilhões até $2022 .{ }^{56}$

No Canadá, onde o uso da maconha para fins recreativos foi liberado recentemente:

Relatório do Statistics Canada divulgado em janeiro mostra que, em 2017, os canadenses gastaram US\$ 5,7 milhões em maconha (prioritariamente para uso recreativo). Segundo o Quartz, a demanda por maconha medicinal e recreativa no país alcançará 575 toneladas em 2021 - o que representaria US\$ 4,5 bilhões em vendas. Já o ministro de finanças canadense disse que o governo espera arrecadar, no mínimo, 300 milhões de dólares canadenses em impostos incididos no comércio de Cannabis. ${ }^{57}$

No Brasil, segundo o estudo elaborado em 2016 por Adriano da Nóbrega Silva, Pedro G. C. Lima e Luciana S. Teixeira, ${ }^{58}$ calcula-se que, com a legalização da maconha, a arrecadação tributária poderá render aproximadamente R\$ 5 bilhões, se considerar os mesmos tributos e alíquotas aplicados sobre o tabaco. Em outro cenário previsto, caso haja o aumento do consumo da maconha, assim como houve no Estado do Colorado, nos Estados Unidos, no período póslegalização, em um primeiro momento a arrecadação tributária poderá atingir R\$ 6 bilhões. Para tanto, afirmam os autores que:

A avaliação do impacto econômico da legalização da Cannabis leva em conta os resultados medidos em termos de receitas geradas e economias alcançadas. As vantagens econômicas da legalização adviriam da geração de receitas de impostos da nova atividade econômica legalizada, da criação de empregos, da redução da evasão de divisas com o enfraquecimento ou mesmo fim do mercado

${ }^{55}$ CUÉ, Carlos E. Uruguai inicia venda de maconha em farmácias e revoluciona a política mundial de drogas. $\quad$ El País, 19 jul. 2017.2 Disponível https://brasil.elpais.com/brasil/2017/07/01/intemacional/1498915815_792114.html. Acesso em: 25 jul. 2018.

56 GRADILONE, Cláudio. Essas ações dão onda? ISTOÉ DINHEIRO, 19 jan. 2018. Disponível em: https: //www. istoedinheiro.com.br/essas-acoes-dao-onda/. Acesso em: 06 ago. 2018.

57 ÉPOCA NEGÓCIOS. Por que o Canadá legalizou o uso recreativo da maconha. Época Negócios Online, 20 jun. 2018. Disponível em: https://epocanegocios.globo.com/Mundo/noticia/2018/06/por-que-o-canadalegalizou-o-uso-recreativo-da-maconha.html. Acesso em: 19 ago. 2018.

58 SILVA, Adriano da Nóbrega; LIMA, Pedro Garrido da Costa; TEIXEIRA, Luciana da Silva. Impacto econômico da legalização da Cannabis no Brasil. Brasília: Consultoria Legislativa da Câmara dos Deputados, abr. 2016, p. 33. 
ilegal e da redução de gastos de policiamento, jurídico-processuais, de encarceramento e com a saúde dos usuários, em razão de um mercado regulado em que haja controle de qualidade do produto. ${ }^{59}$

Entretanto, estas variáveis analisadas estão suscetíveis ao comportamento do mercado consumidor, à regulação do mercado legal, à relação entre a maconha e as demais drogas e ao nível de preços. ${ }^{60}$ Favorável à legalização do plantio da Cannabis e comparando-a aos lucros da indústria do fumo, Ruy Daher observa que:

Em 2015, no Brasil, foram plantados perto de 450 mil hectares de fumo em folha para tabaco legal. Produção de 900 mil toneladas e produtividade de 2.000 $\mathrm{kg} / \mathrm{ha}$, gerando receita de 6 bilhões de reais para o campo, o que fez o tabaco in natura render ao agricultor 6,70 reais por quilo, perto de sete centavos por grama.

$[\ldots]$

O fumo é a oitava cultura mais plantada no Brasil. Representa 2,5\% do valor bruto da produção dos 65 principais plantios. Legalizada e em bases econômicas o que poderia representar para a agricultura do País? ${ }^{61}$

Há, ainda, aspectos econômicos paralelos pouco claros, porque são dependentes de análise científica de áreas interdisciplinares. Por exemplo, o consumo em larga escala sobrecarregaria os serviços públicos de saúde? O estado de maior relaxamento do consumidor, resultante do consumo, pode torná-lo menos produtivo, ao menos em parte do dia, gerando reflexos na economia? Tais questionamentos devem ser levados em conta em uma ampla investigação científica sobre o tema.

\section{REFLEXOS SOBRE O MEIO AMBIENTE}

A preocupação com o estado do meio ambiente é acentuada no Brasil. Se regredirmos no tempo, encontraremos José Bonifácio de Andrada e Silva a alertar, no início do século XIX, sobre a necessidade de ser mantido o equilíbrio na exploração dos recursos naturais:

\footnotetext{
59 SILVA, Adriano da Nóbrega; LIMA, Pedro Garrido da Costa; TEIXEIRA, Luciana da Silva. Impacto econômico da legalização da Cannabis no Brasil. Brasília: Consultoria Legislativa da Câmara dos Deputados, abr. 2016, p. 5.

60 SILVA, Adriano da Nóbrega; LIMA, Pedro Garrido da Costa; TEIXEIRA, Luciana da Silva. Impacto econômico da legalização da Cannabis no Brasil. Brasília: Consultoria Legislativa da Câmara dos Deputados, abr. 2016, p. 33.

61 DAHER, Rui. A legalização da maconha e a economia. Carta Capital, 22 nov. 2016. Disponível em: https://www.cartacapital.com.br/economia/a-legalizacao-da-maconha-e-a-economia. Acesso em: 10 ago. 2018.
} 
Se os canais de rega e navegação aviventam o comércio e a lavoura, não pode havê-los sem rios, não pode haver rios sem fontes, não há fontes sem chuva e orvalhos, não há chuvas e orvalhos sem umidade, e não há umidade sem matas $[\ldots]$. Assim tudo é ligado na imensa cadeia do Universo $[\ldots] .{ }^{62}$

Lenta foi a evolução, com textos de outras áreas, mas com reflexos ambientais (e.g., Decreto 24.645, de 10 de julho de 1934, maus tratos aos animais), até chegar-se à proteção jurídica. Neste sentido, como afirmado:

É preciso deixar expresso que contribuiu grandemente para que se alcançasse a atual situação a Conferência das Nações Unidas sobre o Meio Ambiente, realizada em Estocolmo, Suécia, em junho de 1972. É que a partir daí o mundo voltou os olhos para o tema emergente, o que acabou influindo decisivamente em reformas constitucionais, que foram concretizar-se, principalmente, na década de oitenta. ${ }^{63}$

Porém, foi com a Constituição de 1988 que se deu o grande avanço na área. Além do sempre lembrado artigo 225, que traça as regras de conduta do Estado e da sociedade sobre a questão ambiental, outros tantos a ela se referiram, sempre atrelando o meio ambiente a outros aspectos relevantes. Assim, por exemplo, a atribuição legislativa à União, aos Estados e ao Distrito Federal para legislar sobre meio ambiente e controle da poluição (art. 24, inc. VI), a condicionante do desenvolvimento à sustentabilidade (art. 170, inc. VI), a imposição à propriedade rural da "utilização adequada dos recursos naturais disponíveis e preservação do meio ambiente" (art. 186, inc. II) e a dedicação de um artigo específico e minucioso (art. 216) ao patrimônio cultural brasileiro, que é parte do meio ambiente artificial.

Como anota Paulo Affonso Leme Machado, ${ }^{64}$ na Carta Magna "o direito ao meio ambiente entra na categoria de direito difuso, não se esgotando em uma só pessoa, mas se espraiando para uma coletividade indeterminada". Diante desta preocupação já consolidada em nosso sistema jurídico, evidentemente, o plantio da maconha em larga escala deve ser analisado, também, sob esta ótica. Em outras palavras, é necessário saber se tal procedimento constituiria uma ofensa à preservação de um meio ambiente sustentável. O tema é palco de debates nos Estados Unidos da América, onde a produção é feita em larga escala e os efeitos são sentidos e avaliados com maior cuidado.

\footnotetext{
62 SILVA, José Bonifácio de Andrada e. Apud: PÁDUA, José Augusto. Um sopro de destruição. Rio de Janeiro: Jorge Zahar Ed., 2002, p. 139.

63 FREITAS, Vladimir Passos de. A Constituição Federal e a efetividade das normas ambientais. São Paulo: Revista dos Tribunais, 2000, p. 26.

${ }^{64}$ MACHADO, Paulo Affonso Leme. Direito Ambiental Brasileiro. 26. ed. São Paulo: Malheiros, 2018, p. 158.
} 
0 primeiro aspecto a merecer análise diz respeito ao uso da água para a rega. Segundo reportagem sobre a seca de 2014 no Estado da Califórnia, “cada planta de maconha consome de 20 a 40 litros de água, de acordo com o ponto do seu ciclo de crescimento. Em comparação, um pé de alface, outra das principais culturas da Califórnia, precisa de cerca de 13 litros de água”. ${ }^{65}$ Ainda:

São necessários 5.900 litros de água para produzir um quilo de lentilhas. Grão-debico exige menos do que a lentilha, com 4.200 litros $/ \mathrm{kg}$, e a soja utiliza menos do que o tofu processado, cerca de 2.160 litros $/ \mathrm{kg}$. Todas essas opções são melhores em termos de economia de água do que comer carne bovina, de carneiro ou de porco. ${ }^{66}$

É certo, ainda, que os produtos de origem vegetal gastam menos dos que os de origem animal. Diante de tais dados, no Brasil não há por que considerar-se excessiva a necessidade de água para a produção da maconha.

Mas, por vezes, a questão vai além dos recursos hídricos, como observa reportagem de Melati Kaye sobre as preocupações ambientais existentes na Califórnia, estado que produz 60\% da maconha consumida nos Estados Unidos. Revela a matéria que:

De acordo com o Departamento de Justiça, a maior parte vem dos três condados do norte do Triângulo Esmeralda: Mendocino, Humboldt e Trinity. As condições aqui são consideradas perfeitas para o cultivo de maconha ao ar livre. Mas isso provou ser uma bênção muito ambígua para a região, trazendo consigo uma série de perturbações ambientais para os canais locais e a vida selvagem. Desvios de riachos ameaçam o habitat dos peixes e estimulam a proliferação de algas tóxicas. A construção de estradas e cortes rasos corroem o solo e os fluxos de nuvens. ${ }^{67}$

O uso da energia é outro fator importante para se avaliar o efeito da plantação da Cannabis sobre o meio ambiente. Nos Estados Unidos, em especial em estados de baixas temperaturas como o Oregon, o plantio é feito em recintos fechados, denominados estufas, do que resulta significativo consumo de energia. Segundo Douglas Afonso de Souza Costa et al.:

${ }^{65}$ RYZIK, Melena. Produtores de maconha 'roubam' água de nascentes e lagos em plena seca nos EUA. Uol, 08 ago. 2014. Disponível em: https://noticias.uol.com.br/internacional/ultimas-noticias/the-new-yorktimes/2014/08/08/produtores-de-maconha-roubam-agua-de-nascentes-e-lagos-em-plena-seca-noseua.htm?cmpid=copiaecola. Acesso em: 16 ago. 2018.

66 BONDE. QUANTOS litros de água são usados para produção dos nossos alimentos? Disponível em: https: / / www.bonde.com.br/saude/tire-suas-duvidas/quantos-litros-de-agua-sao-usados-para-producaodos-nossos-alimentos--391531.html. Acesso em: 20 jul. 2018.

67 KAYE, Melati. Burgeoning marijuana market prompts concerns about crop's environmental impact. Scientific American, 2 fev. 2017.2 Disponível https://www.scientificamerican.com/article/burgeoning-marijuana-market-prompts-concerns-aboutcrop-rsquo-s-environmental-impact/. Acesso em: 15 ago. 2018. 
O cultivo indoors de maconha exige um consumo muito elevado de energia, principalmente por dois fatores: o nível da luz, que é comparável ao utilizado em salas de operação de hospitais (500 vezes maior que o recomendado para leitura); e a troca do ar, da ordem de 30 vezes por hora (6 veze maior que em laboratórios de alta tecnologia) (MILLS, 2012). A densidade de potência resultante é da ordem de $2000 \mathrm{~W} / \mathrm{m}^{2}$, que é comparável à de data centers modernos (MILLS, 2012). ${ }^{68}$

Se este é um problema para aquela região dos Estados Unidos, é também, com certeza, para o Canadá, onde as temperaturas são mais baixas. No entanto, não seria um problema no Brasil. Nosso país tem temperaturas altas na maior parte de seu território, predominando o clima tropical, sendo que apenas na região sul o clima é temperado.

Atualmente, planta-se maconha de forma ilícita em nosso território para abastecimento do mercado interno, em especial na região do Polígono das Secas, que compreende parte do Nordeste brasileiro e o norte de Minas Gerais. Este cultivo, com certeza, deve causar danos ambientais, principalmente porque o uso da terra e o consumo da água são feitos à total revelia dos órgãos de controle. Contudo, do ponto de vista do uso de energia elétrica, considerando o clima do Polígono das Secas, presume-se que não ocorram maiores danos ambientais.

Há, ainda, um aspecto paralelo que merece registro, qual seja, o social, relacionado com os que se dedicam ao plantio ilícito. Segundo reportagem de Bárbara Duque (2015, p. 43), baseada em pesquisa do professor Paulo Fraga, da Universidade Federal de Juiz de Fora:

Os desafios de trabalhar em cultura ilícita são diversos. Apesar de ser uma opção sustentável, coloca a vida do agricultor e de seus familiares em risco. São ao mesmo tempo vítimas e cúmplices. Na maioria das relações de trabalho é deles a responsabilidade de "tomar conta" da plantação, ou seja, durante os três meses de cultivo da safra, os agricultores devem morar nas roças, evitando o roubo. Como se trata de uma atividade ilícita, não há lei que os ampare. ${ }^{69}$

À vista de todo o exposto, é possível concluir que eventual permissão para que se cultive maconha no Brasil trará múltiplas consequências, porém, do ponto de vista estritamente ambiental, elas não vão além do risco comum a qualquer atividade na agricultura. Evidentemente, em tal hipótese o local da plantação deve ser avaliado corretamente, sob pena

${ }^{68}$ COSTA, Douglas Afonso de Souza; BOY, Matheus Ferreira Machado; CAETANO, Thiago Rosário. Tornando a cannabis mais verde: impacto ambiental do cultivo indoors de maconha e alternativas. Ciências do Ambiente - UNICAMP, 2014, p. $\quad 3 . \quad$ Disponível em: http://www.ib.unicamp.br/dep_biologia_animal/sites/www.ib.unicamp.br.dep_biologia_animal/files/Im pactoAmb_Canabis\%20In\%20Doors.pdf. Acesso em: 16 ago. 2018.

${ }^{69}$ DUQUE, Bárbara. O plantio da maconha visto pela ótica social. Revista A3, mai/out. 2015. Disponível em: http://www.ufjf.br/revistaa3/files/2015/09/A308_WEB.40-43.pdf. Acesso em 16 ago. 2018, p. 43. 
REFLEXOS DA LIBERAÇÃO DA MACONHA SOBRE O MEIO AMBIENTE

de o desenvolvimento econômico da atividade revelar-se insustentável e ambientalmente danoso.

\section{CONCLUSÃO}

Ao final, percorrido o trajeto em área do Direito carente no Brasil de pesquisas e até mesmo de debates, é possível chegar-se a algumas conclusões, entre as quais avultam os reflexos da liberação do plantio da maconha sobre o meio ambiente em nosso território.

A primeira observação que se faz é a respeito do alcance do tema. 0 foco foi sobre a proteção do meio ambiente, principalmente por tratar-se de abordagem pioneira. No entanto, como não poderia deixar de ser, a investigação finda por abordar aspectos interligados, como a saúde e a questão social, sem os quais a pesquisa ficaria incompleta.

Entre as conclusões a que se chega, está, em primeiro plano, a de que a descriminalização do uso da Cannabis é uma tendência, com elevada possibilidade de tornar-se realidade, na medida em que a sociedade vem se mostrando mais tolerante quanto a tal prática e o número de usuários, a qualquer título, cresce continuamente.

Eventual mudança, contudo, dependerá, da orientação política dos Poderes da República, podendo ter fases mais restritivas alternadas com outras de maior tolerância. A alteração do regramento da matéria poderá ser fruto de nova legislação, a depender das inclinações do Parlamento, ou de decisão judicial oriunda do Supremo Tribunal Federal.

Conclui-se, todavia, que a descriminalização através de decisão judicial não é a melhor forma de solução para o assunto, porque é grande a possibilidade de que se incline por uma posição concessiva sem a necessária análise de todos os aspectos envolvidos, entre eles os efeitos sobre o meio ambiente. Não raramente, decisões da Corte Suprema definem intrincada questão jurídica, sem atentar para todos os seus reflexos.

Tal fato dá-se porque nosso sistema de Justiça atribui ao órgão máximo uma ampla e incomum competência, o que impede dar-se a cada caso o tempo e o amadurecimento necessários para que todos os aspectos, inclusive as consequências sociais e econômicas, mereçam uma menção específica. Em um país com dimensões continentais como o Brasil, com uma grande diversidade cultural e econômica, é evidente que disto resulta grande risco de surgirem, posteriormente, situações insolúveis.

Sendo permitido o uso para efeitos medicinais, hipótese mais plausível e que encontra justificativas fortes sob o ponto de vista da saúde (face à utilidade para o paciente em 
REFLEXOS DA LIBERAÇÃO DA MACONHA SOBRE O MEIO AMBIENTE

determinadas moléstias) ou econômicas (atualmente é permitida a importação, mas os valores são elevados), o plantio para abastecer o mercado consumidor será feito em escala comercial. Isto resultará em investimentos econômicos, com reflexos na comunidade, na vida dos possíveis usuários e suas famílias. Obviamente, será impossível fazer-se o controle absoluto da destinação da substância, mas a quantia destinada ao paciente em cada caso será prescrita por um médico, ciente da necessidade do cliente.

Caso a liberação se estenda a fins recreativos, os investimentos serão, com certeza, maiores, e os reflexos se estenderão primordialmente à economia dos estados e municípios em que o plantio se exerça e, em menor escala, às finanças da União, através do ingresso de tributos. Face à extensão do nosso território, será difícil o Poder Público, seja qual for a esfera de governo, vir a ser produtor e fornecedor, devendo a atividade ser feita pela iniciativa privada, com regulação e fiscalização pelo Estado. Se um país como o Uruguai, com pequeno território e uma população que equivale a $5 \%$ da brasileira, já tem dificuldades em exercer tal tipo de controle, fácil é concluir que o Brasil as teria de forma agravada.

Finalmente, do ponto de vista dos reflexos ambientais, em caso de plantio em grande quantidade é possível concluir que os danos ambientais não terão maior relevância, porque serão os mesmos existentes em qualquer atividade na agricultura. Evidentemente, em tal hipótese, as plantações se sujeitarão, como as outras práticas agrícolas, ao respeito às regras existentes (e.g., proteção de áreas de proteção permanente previstas no Código Florestal) e respectivo controle dos órgãos de proteção ao meio ambiente.

\section{REFERÊNCIAS}

BATISTA, Everton Lopes. Empresas do país ajudam pacientes a achar médicos que prescrevam maconha. Jornal Folha de São Paulo, 30 nov. 2018.

BBC. Canadá legaliza uso recreativo da maconha: saiba em que lugares o uso da droga é permitido. BBC News Brasil, 20 jun. 2018. Disponível em:

https://www.bbc.com/portuguese/internacional-44545870. Acesso em: 19 ago. 2018.

BONDE. QUANTOS litros de água são usados para produção dos nossos alimentos? Disponível em: https://www.bonde.com.br/saude/tire-suas-duvidas/quantos-litros-de-agua-sao-usados-paraproducao-dos-nossos-alimentos--391531.html. Acesso em: 20 jul. 2018.

BONFÁ, Laura; VINAGRE, Ronaldo C. O.; FIGUEIREDO, Núbia V. Uso de canabinóides na dor crônica e em cuidados paliativos. Revista Brasileira de Anestesiologia, vol. 58, n. 3, maio/jun. 2008. 
REFLEXOS DA LIBERAÇÃO DA MACONHA SOBRE O MEIO AMBIENTE

BRASIL. Decreto ${ }^{\circ} 154$, de 26 de junho de 1991. Promulga a Convenção Contra o Tráfico llícito de Entorpecentes e Substâncias Psicotrópicas. In: Diário Oficial da União, Brasília, DF, 27 dez. 1968. Disponível em: http://www.planalto.gov.br/ccivil_03/decreto/1990-1994/D0154.htm. Acesso em: 3 ago. 2018.

BRASIL. Decreto $n^{\circ} 847$, de 11 de outubro de 1890. Promulga o Código Penal. In: Coleção de Leis do Brasil, Brasília, DF, 1890. Disponível em:

http://www2.camara.leg.br/legin/fed/decret/1824-1899/decreto-847-11-outubro-1890-503086publicacaooriginal-1-pe.html. Acesso em: 18 jul. 2018.

BRASIL. Decreto-Lei no 385, de 26 de dezembro de 1968. Dá nova redação ao artigo 281 do Código Penal. In: Diário Oficial da União, Brasília, DF, 27 dez. 1968. Disponível em: <http://www.planalto.gov.br/ccivil_03/decreto-lei/1965-1988/Del0385.htm\#art281>. Acesso em: 18 jul. 2018.

BRASIL. Decreto-lei $n^{\circ} 2.848$, de 7 de dezembro de 1940. Código Penal. In: Diário Oficial da União, Brasília, DF, 31 dez. 1940. Disponível em:

http://www2.camara.leg.br/legin/fed/declei/1940-1949/decreto-lei-2848-7-dezembro-1940412868-publicacaooriginal-1-pe.html. Acesso em; 18 jul. 2018.

BRASIL. Lei $n^{\circ} 6.368$, de 21 de outubro de 1976. Dispõe sobre medidas de prevenção e repressão ao tráfico ilícito e uso indevido de substâncias entorpecentes ou que determinem dependência física ou psíquica, e dá outras providências. In: Diário Oficial da República Federativa do Brasil, Brasília, DF, 22 out. 1976. Disponível em: http://www.planalto.gov.br/ccivil_03/LEIS/L6368.htm\#art46. Acesso em: 18 jul. 2018.

BRASIL. Lei $n^{\circ} 11.343$, de 23 de agosto de 2006. Institui o Sistema Nacional de Políticas Públicas sobre Drogas - Sisnad; prescreve medidas para prevenção do uso indevido, atenção e reinserção social de usuários e dependentes de drogas; estabelece normas para repressão à produção não autorizada e ao tráfico ilícito de drogas; define crimes e dá outras providências. In: Diário Oficial da República Federativa do Brasil, Brasília, DF, 24 ago. 2006. Disponível em: http://www.planalto.gov.br/ccivil_03/_Ato2004-2006/2006/Lei/L11343.htm\#art75. Acesso em: 18 jul. 2018.

BRASIL. Lei de 16 de dezembro de 1830. Manda executar o Codigo Criminal. In: Coleção de Leis do Brasil, Brasília, DF, 1830. Disponível em:

http://www.planalto.gov.br/ccivil_03/leis/LIM/LIM-16-12-1830.htm. Acesso em: 18 jul. 2018.

BRASIL. Supremo Tribunal Federal. Ação Direta de Inconstitucionalidade $n^{\circ}$ 635.659. Relator: Ministro Gilmar Mendes, distribuída em 1 de março de 2011. Disponível em:

http: / / www.stf.jus.br/portal/processo/verProcessoAndamento.asp?incidente $=4034145$. Acesso em: 16 ago. 2018.

BRAUN, Ivan Mario. Drogas: perguntas e respostas. São Paulo: MG, 2007.

BRUZA, Rafael. Juiz dá salvo-conduto para paciente plantar maconha com fins medicinais. Independente, 26 maio 2018. Disponível em: http://independente.jor.br/juiz-da-salvo-condutopara-paciente-plantar-maconha-com-fins-medicinais/. Acesso em: 04 ago. 2018. 
REFLEXOS DA LIBERAÇÃO DA MACONHA SOBRE O MEIO AMBIENTE

BULLOCK, Nicole. PRIMEIRA produtora de maconha a abrir capital nos EUA estreia com alta de 32\%. Folha de São Paulo, São Paulo, A10, 20 jul. 2018.

COSTA, Douglas Afonso de Souza; BOY, Matheus Ferreira Machado; CAETANO, Thiago Rosário. Tornando a cannabis mais verde: impacto ambiental do cultivo indoors de maconha e alternativas. Ciências do Ambiente - UNICAMP, 2014, p. 3. Disponível em:

http://www.ib.unicamp.br/dep_biologia_animal/sites/www.ib.unicamp.br.dep_biologia_animal /files/ImpactoAmb_Canabis\%20In\%20Doors.pdf. Acesso em: 16 ago. 2018.

CUÉ, Carlos E. Uruguai inicia venda de maconha em farmácias e revoluciona a política mundial de drogas. El País, 19 jul. 2017. Disponível em:

https://brasil.elpais.com/brasil/2017/07/01/internacional/1498915815_792114.html. Acesso em: 25 jul. 2018.

DAHER, Rui. A legalização da maconha e a economia. Carta Capital, 22 nov. 2016. Disponível em: https://www.cartacapital.com.br/economia/a-legalizacao-da-maconha-e-a-economia. Acesso em: 10 ago. 2018.

DUQUE, Bárbara. O plantio da maconha visto pela ótica social. Revista A3, mai/out. 2015. Disponível em: http://www.ufjf.br/revistaa3/files/2015/09/A308_WEB.40-43.pdf. Acesso em 16 ago. 2018.

ÉPOCA NEGÓCIOS. Por que o Canadá legalizou o uso recreativo da maconha. Época Negócios Online, 20 jun. 2018. Disponível em:

https://epocanegocios.globo.com/Mundo/noticia/2018/06/por-que-o-canada-legalizou-o-usorecreativo-da-maconha.html. Acesso em: 19 ago. 2018.

ÉPOCA NEGÓCIOS. Por que os coffeeshops de Amsterdã estão fechando? Época Negócios Online, 03 fev. 2017. Disponível em: https://epocanegocios.globo.com/colunas/Coffee-

Break/noticia/2017/02/por-que-os-coffeeshops-de-amsterda-estao-fechando.html. Acesso em: 06 ago. 2018.

FILIPINAS. Câmara das Filipinas aprova pena de morte para crime relacionado a droga. Folha de São Paulo (digital), caderno Mundo, 7/3/2017. Disponível em:

https://www1.folha.uol.com.br/mundo/2017/03/1864279-camara-das-filipinas-aprova-pena-demorte-para-crime-relacionado-a-droga.shtml. Acesso em 27 nov. 2018.

FILIPINAS. Comprehensive dangerous drugs act of 2002. Disponível em:

https: / / www.wipo.int/wipolex/en/text.jsp?file_id=480318,\%20filipinas. Acesso em 27 nov. 2018.

FRANÇA, Jean Marcel Carvalho. História da maconha no Brasil. São Paulo: Três Estrelas, 2015.

FREITAS, Vladimir Passos de. A Constituição Federal e a efetividade das normas ambientais. São Paulo: Revista dos Tribunais, 2000.

G1. Veja como é a legislação relativa à maconha em outros países. G1 Mundo, 10 dez. 2013. Disponível em: http://g1.globo.com/mundo/noticia/2013/12/veja-como-e-legislacao-relativamaconha-em-outros-paises.html. Acesso em: 12 ago. 2018. 
REFLEXOS DA LIBERAÇÃO DA MACONHA SOBRE O MEIO AMBIENTE

GAÚCHAZH. Disputa por mercado de maconha provoca aumento no índice de homicídios no Uruguai. Disponível em: https://gauchazh.clicrbs.com.br/grupo-deinvestigacao/noticia/2019/01/disputa-por-mercado-de-maconha-provoca-aumento-no-indice-dehomicidios-no-uruguai-cjr2blcwd01pl01pkcb2wmgry.html. Acesso em: 25 jul. 2019.

GRADILONE, Cláudio. Essas ações dão onda? ISTOÉ DINHEIRO, 19 jan. 2018. Disponível em: https://www.istoedinheiro.com.br/essas-acoes-dao-onda/. Acesso em: 06 ago. 2018.

HOLANDA. Am I committing a criminal offence if I possess, produce or deal in drugs? Disponível em: https://www.government.nl/topics/drugs/am-i-committing-a-criminal-offenceif-i-possess-produce-or-deal-in-drugs. Acesso em: 06 ago. 2018.

HOLANDA. Opiumwet (Opium Act). WHO MiNDbank Collection: 12 de maio de 1928. Disponível em: https://www.mindbank.info/item/2026. Acesso em: 06 ago. 2018.

HOLANDA. Toleration policy regarding soft drugs and coffee shops. Disponível em: https: / / www.government.nl/topics/drugs/toleration-policy-regarding-soft-drugs-and-coffeeshops. Acesso em: 06 ago. 2018.

HONÓRIO, Káthia Maria; ARROIO, Agnaldo; SILVA, Albérico B. F. Aspectos terapêuticos de compostos da planta Cannabis sativa. Química Nova, vol. 23, n. 2, pp. 318-325, 2006.

JESUS, Antonio Carlos Justo de; FERNANDES, Luis Rodrigues; ELIAS, Paloma Sampaio; SOUZA, André Ricardo Gomes de. Legalização da maconha para fins medicinais. Revista do Curso de Direito da Universidade Braz Cubas, v. 1, n. 1, maio 2017. Disponível em:

https://revistas.brazcubas.br/index.php/revdubc/article/view/247/399. Acesso em: 12 ago. 2018.

KALANT, Harold. Medicinal use of Cannabis: history and current status. Pain Research and Management, vol. 6, n. 2, summer 20.

KAYE, Melati. Burgeoning marijuana market prompts concerns about crop's environmental impact. Scientific American, 2 fev. 2017. Disponível em:

https: / / www.scientificamerican.com/article/burgeoning-marijuana-market-prompts-concernsabout-crop-rsquo-s-environmental-impact/. Acesso em: 15 ago. 2018.

MACHADO, Paulo Affonso Leme. Direito Ambiental Brasileiro. 26. ed. São Paulo: Malheiros, 201.

MENDES, Oro. 14 anos após descriminalizar todas as drogas, é assim que Portugal está no momento. Awebic, 07 fev. 2018. Disponível em: https://awebic.com/democracia/comoportugal-descriminalizou-as-drogas-e-e-um-exemplo-para-o-mundo/. Acesso em: 06 ago. 2018.

MORI, Letícia. Como o uso de maconha medicinal tem crescido no Brasil. Disponível em: https://www.bbc.com/portuguese/geral-44283537. Acesso em: 27 nov. 2018.

NORML. Colorado laws and penalties. Disponível em: http://norml.org/laws/item/coloradopenalties. Acesso em: 19 ago. 2018.

NORML. Kansas laws and penalties. 2018b. Disponível em: http://norml.org/laws/item/kansaspenalties-2. Acesso em: 19 ago. 2018. 
REFLEXOS DA LIBERAÇÃO DA MACONHA SOBRE O MEIO AMBIENTE

NORML. Kentucky laws and penalties. Disponível em: http://norml.org/laws/item/kentuckypenalties-2. Acesso em: 19 ago. 2018.

NORML. Maine laws and penalties. Disponível em: http://norml.org/laws/item/mainepenalties-2. Acesso em: 19 ago. 2018.

NORML. State Laws. Disponível em: http://norml.org/laws. Acesso em: 19 ago. 2018.

NORML. Virginia laws and penalties. Disponível em: http://norml.org/laws/item/virginiapenalties-2. Acesso em: 19 ago. 2018.

NORML. Wyoming laws and penalties. Disponível em: http://norml.org/laws/item/wyomingpenalties-2. Acesso em: 19 ago. 2018.

PORTUGAL. Lei n 33, de 18 de julho de 2018. In: DRE - Diário da República Eletrônico, n. ${ }^{\circ}$ 137/2018. Disponível em: https://dre.pt/home/-/dre/115712242/details/maximized. Acesso em: 04 ago. 2018.

PORTUGAL. Ordenações Filipinas: Livro V. Disponível em:

http://www1.ci.uc.pt/ihti/proj/filipinas/l5ind.htm. Acesso em: 25 jul. 2018.

ROBINSON, Melia. This map shows every state that has legalized marijuana. Business Insider Nordic, 23 jan. 2018. Disponível em: https://nordic.businessinsider.com/legal-marijuana-states2018-1/. Acesso: 04 ago. 2018.

ROWAN, Robinson. 0 grande livro da Cannabis: guia completo de seu uso industrial, medicinal e ambiental. Rio de Janeiro: Jorge Zahar, 1999.

RYZIK, Melena. Produtores de maconha 'roubam' água de nascentes e lagos em plena seca nos EUA. Uol, 08 ago. 2014. Disponível em: https://noticias.uol.com.br/internacional/ultimasnoticias/the-new-york-times/2014/08/08/produtores-de-maconha-roubam-agua-de-nascentes-elagos-em-plena-seca-nos-eua.htm?cmpid=copiaecola. Acesso em: 16 ago. 2018.

SILVA, Adriano da Nóbrega; LIMA, Pedro Garrido da Costa; TEIXEIRA, Luciana da Silva. Impacto econômico da legalização da Cannabis no Brasil. Brasília: Consultoria Legislativa da Câmara dos Deputados, abr. 2016.

SILVA, José Bonifácio de Andrada e. Apud: PÁDUA, José Augusto. Um sopro de destruição. Rio de Janeiro: Jorge Zahar Ed., 2002.

SINGAPURA. Misuse of drugs act (Chapter 185). Revised edition 2008 (Original enactment: act 5 of 1973). Singapore statutes online. Disponível em: https://sso.agc.gov.sg/Act/MDA1973. Acesso em: 27 nov. 2018.

TRUMBLE, Sarah; DECKER, James. Map of State Marijuana Legalization Laws. Third Way, 2 fev. 2018. Disponível em: https://www.thirdway.org/infographic/map-of-state-marijuanalegalization-laws. Acesso em: 04 ago. 2018. 
URUGUAI. Decreto-Lei 14.294, de 31 de outubro de 1974. Disponível em:

https: / / legislativo.parlamento.gub.uy/temporales/leytemp7057670.htm. Acesso em: 3 ago. 2018.

URUGUAI. Lei $\mathrm{n}^{\circ}$ 19.172, de 7 de janeiro de 2014. Disponível em: https://legislativo.parlamento.gub.uy/temporales/leytemp6844441.htm. Acesso em: 3 ago. 2018.

VEJA. Anvisa reconhece 'Cannabis sativa' como planta medicinal. Veja Saúde, 16 maio 2017. Disponível em: https://veja.abril.com.br/saude/anvisa-reconhece-Cannabis-sativa-como-plantamedicinal/. Acesso em: 04 ago. 2018.

ZAGANELLI, Margareth Vetis; CORREIA, João Victor Gomes. A restrição do uso medicinal da cannabis sativa face ao princípio da autonomia da vontade. Revista Eletrônica do Curso de Direito. Universidade Federal de Santa Maria, v. 13, $\mathrm{n}^{\circ} 2$ 2, 2018, p. 10. Disponível em: https://periodicos.ufsm.br/revistadireito/article/view/29501/pdf. Acesso em 28 jul. 2019.

Recebido em: 06.02.2019 / Revisões requeridas em: 20.07.2019 / Aprovado em: 14.09.2019 / Publicado em: 05.01.2020

\section{COMO FAZER REFERÊNCIA AO ARTIGO (ABNT):}

FREITAS, Vladimir Passos de. Reflexos da liberação da maconha sobre o meio ambiente. Revista Eletrônica do Curso de Direito da UFSM, Santa Maria, RS, v. 15, n. 1, e36787, jan./abr. 2020. ISSN 1981-3694. DOI: http://dx.doi.org/10.5902/1981369436787. Disponível em:

https://periodicos.ufsm.br/revistadireito/article/view/36787 Acesso em: dia mês. ano.

Direitos autorais 2020 Revista Eletrônica do Curso de Direito da UFSM

Editores responsáveis: Rafael Santos de Oliveira e Angela Araujo da Silveira Espindola

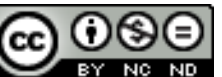

Esta obra está licenciada com uma Licença Creative Commons Atribuição-NãoComercial-SemDerivações 4.0 Internacional.

\section{SOBRE O AUTOR}

VLADIMIR PASSOS DE FREITAS

É licenciado em Direito pela Faculdade Católica de Direito de Santos (1968), mestre e doutor em Direito pela Universidade Federal do Paraná (1989 e 1999) e pós-doutor pela Universidade de São Paulo (USP), na área de Saúde Pública. Foi Promotor de Justiça nos Estados do PR e SP (10 anos) e Juiz Federal (26 anos), tendo exercido a presidência do Tribunal Regional Federal da 4a. Região . Aposentado do cargo de Desembargador Federal em 2006, atualmente é professor de Direito Ambiental da graduação e da pós-graduação da Pontifícia Universidade Católica do Paraná, membro do Grupo de Especialistas em Judiciário da International Union For Conservation Of Nature, conferecista internacional na área do Direito Ambiental e em Política Judiciária e Administração da Justiça, sendo fundador e vice-presidente do Instituto Brasileiro de Administração do Sistema Judicial - IBRAJUS e ex-Presidente da "International Association for Courts Administration - IACA", com sede em Arlington, VA, Estados Unidos da América. Membro da "Associação de Professores de Direito Ambiental APRODAB" , com sede em São Paulo, Brasil, e da "Asociacion Internacional de professores de Derecho Ambiental", sede em Lima, Peru. Doutor ?Honoris Causa em Humanidades?, outorgado pela Universidad Paulo Freire, Manágua, Nicarágua e Professor Visitante da Escuela de Administración de la Facultad de Ciencias Sociales de la Universidad Nacional de Costa Rica.. Membro do Instituto dos Advogados Brasileiros. Membro do Conselho Nacional do Meio Ambiente - CONAMA, na qualidade de representante do Ministério da Justiça, a partir de 20 de março de 2019. Chefe da Assessoria Especial de Assuntos Legislativos do Ministério da Justiça e Segurança Pública. 